\title{
Quality Systems for Microscopy \& Microanalysis: ISO 9000 and more
}

\author{
Eric Steel, National Institute of Standards \& Technology, Gaithersburg MD 208998371
}

How do you judge the performance of your microscopy and microanalysis lab? How do you know you are giving the correct answer? Learn what other microscopists and microanalysts are doing to help assure the quality of their organization's results. Quality standards for ISO 9000, QS9000, Six Sigma, ISO 17025, etc. have many things in common. These include a system for the quality of management, staff, laboratory, measurement methods, equipment, sampling, and reporting results.

Aimed at the physical sciences, a discussion of internal approaches and documentation will be given by a group of professionals who have experienced it first hand. The discussion will also include how to approach external evaluation and recognition of performance systems such as interlaboratory round robins/proficiency testing, external auditors, accreditation, etc.

What is ISO 9000, QS 9000, AS 9000? ISO 9000 is a family of standards approved by the International Standards Organization (ISO) that defines quality management practices for organizations (private, public, etc.). Organizations that conform to these standards can receive ISO 9000 certification from an accredited registrar. This doesn't necessarily mean that the organization's products have high quality; only that the company follows well-defined procedures for ensuring the quality of their management and products. (Automotive manufacturers use a variant of ISO 9000 called QS 9000 and the Aerospace industry uses AS 9000.)

What is ISO 17025? ISO 17025 is a quality management standard for testing \& calibration laboratories. It integrates the requirements of ISO $9001 \& 9002(1994)$ and contains specifications for quality management requirements but also those based on technical competency \& the ability to generate technically valid results.

Typically, ISO 9000 is aimed at business related activities and ISO 17025 at laboratory related functions. These standards are constantly evolving. For example, ISO 9000-2000 is the latest version and is new enough that most organizations have not yet addressed the changes instituted since the ISO 9000-1994 version. There are other quality related approaches (Six Sigma, Total Quality Management, Malcolm Baldridge National Quality Award, etc.) and we can be assured that more will be created in the future. Picking the right approach for your work is crucial and is often driven by customer needs or large scale company drivers.

A laboratory can use these international standards to 1) help assure their customers of the quality of the work and 2) as guides to improve, monitor, and maintain consistent level of quality in the microscopy laboratory.

The basic steps include, developing and documenting a system that covers all the major functions of your laboratory - for management (defining responsibilities, interaction with clients, control of records, etc.), for technical areas (staff qualifications, facilities, equipment, calibration, analysis methods, sampling, sample handling, and reporting), internal and external assessment of laboratory quality system through audits, interlaboratory comparisons and proficiency testing. 
The tutorial will cover these and more aspects of quality systems. Several representatives of microscopy labs that have gone through the ISO 9000 and 17025 process will be present to answer questions and give advice.

How can you get more information to start learning about quality systems? Here are some web sites and organizations that have information and connections to help you start to set up your quality system.

General Quality Related Links':

The American Society for Quality: http://WwW.asq.org/

The Baldrige National Quality Program http:///wWw.quality.nist.gov"

The Independent Association of Accredited Registrars (IAAR): hittp://Www.iaar.org!

Quality Digest: http://Www.qualitydigest.com/

The automotive industry action group (QS 9000 related): http://www.aiag.org/

The _ National _ _ Aerospace _ and _ Defense Contractors Accreditation program http://www.pri.sae.org/NADCAP/nadcap.htni

$\underline{\text { ISO } 9000 \text { - Business Management \& Quality Related }}$

ISO/Technical _ _ Committee _ _ 176 _ f frequently asked questions about ISO 9000: 'http://_www.tc176.org/fags/index.htmi

The Registrar Accrededitation_ Board: 'http://w_ww.rabnet.com/index_shtmil

$\underline{\text { ISO } 17025 \text { - Calibration \& Testing Laboratory Related }}$

General_172025 information: 'http://wwww.fasor.com/iso25'/

The Laboratory Acçreditation Bureau 'http:L/_қшщ.1-a-b.com/

The National Voluntary_Accreditation Program - : 'http:L/ts.nist_gov/ts/htdocs/210/21-4/214.htm

The American_Association, for Laboratory Accreditation 'http://_kwatz.el2la.erg

${ }^{1}$ We have provided links to sites because it has information that may be of interest. NIST does not necessarily endorse the views expressed or the facts presented on these sites. Further, NIST does not endorse any commercial products that may be advertised or available on these sites. 